\title{
Analisis Faktor-Faktor Yang Mempengaruhi Kebijakan Dividen
}

\author{
${ }^{1}$ Melanthon Rumapea, ${ }^{2}$ Dimita H.P. Purba \\ ${ }^{1,2}$ Fakultas Ekonomi UMI \\ melanthonrumapea@gmail.com, dimitahppurba@gmail.com
}

\begin{abstract}
The objective of the research was to examine the influence of Profitability Growth and Investment Decision on Dividend Policy with Debt Policy as Moderating variables in manufacture companies listed in BEI (Indonesia Stock Market) in the period of 2012 - 2016. The research used causal research method. The population was 138 manufacture companies listed in BEI in the period of 2012-2016, and 85 of them were used as the samples, taken by using purposive sampling technique. The number of observations that is as much as 425 data analysis is by 5 years observation 85 companies. The data were analyzed by using residual test. The result of this study showed that simultaneously the variables of Profitability, Growth and Investment Decision had influence on Dividend Policy. Partially, Profitability had significant positive influence on Dividend Policy, and Investment Decision had significant positive influence on Dividend Policy. The variables of Debt Policy is moderating variables to explain influence Profitability, Growth and Invsetment Decision) on Dividend Policy.
\end{abstract}

\section{Keywords: Profitability, Growth, Investment Decision, Debt Policy, Dividend Policy}

Abstrak. Tujuan dari penelitian ini adalah untuk menguji pengaruh Pertumbuhan Profitabilitas dan Keputusan Investasi terhadap Kebijakan Dividen dengan Kebijakan Utang sebagai variabel Pemoderasi pada perusahaan manufaktur yang terdaftar di BEI (Pasar Saham Indonesia) periode 2012 - 2016. Penelitian ini menggunakan metode penelitian kausal . Populasi adalah 138 perusahaan manufaktur yang terdaftar di BEI pada periode 2012-2016, dan 85 di antaranya digunakan sebagai sampel, diambil dengan menggunakan teknik purposive sampling. Jumlah pengamatan yaitu sebanyak 425 analisis data dengan pengamatan 5 tahun 85 perusahaan. Data dianalisis dengan menggunakan uji residual. Hasil penelitian ini menunjukkan bahwa secara simultan variabel Profitabilitas, Pertumbuhan dan Keputusan Investasi berpengaruh terhadap Kebijakan Dividen. Secara parsial, Profitabilitas berpengaruh positif signifikan terhadap Kebijakan Dividen, dan Keputusan Investasi memiliki pengaruh positif signifikan terhadap Kebijakan Dividen. Variabel Kebijakan Hutang adalah variabel moderasi untuk menjelaskan pengaruh Profitabilitas, Pertumbuhan dan Keputusan Investasi) terhadap Kebijakan Dividen.

\section{Kata kunci: Profitabilitas, Keputusan Investasi, Kebijakan Hutang, Kebijakan Dividen}




\section{A. Pendahuluan}

Sebuah perusahaan yang baik harus mampu mengontrol potensi finansial maupun potensi non finansial dalam meningkatkan nilai perusahaan untuk eksistensi perusahaan dalam jangka panjang. Memaksimalkan nilai perusahaan sangat penting artinya bagi suatu perusahaan, karena tujuan utama perusahaan adalah untuk memaksimalkan nilai perusahaan yang berarti juga dapat memaksimalkan kemakmuran para pemegang saham. Para investor dalam melakukan investasi saham menginginkan keuntungan yaitu berupa dividend yield maupun capital gain, akan tetapi dalam berinvestasi saham juga mengandung risiko.

Tujuan utama dari pendirian perusahaan adalah untuk memaksimalkan nilai pemegang saham. Nilai pemegang saham akan meningkat apabila nilai perusahaan meningkat yang ditandai dengan tingkat pengembalian investasi yang tinggi kepada para pemengang saham. Setiap perusahaan yang terdaftar di Bursa Efek Indonesia (BEI) menginginkan harga saham yang dijual memiliki potensi harga tinggi dan menarik minat para investor untuk membelinya.

Suatu perusahaan agar dapat melangsungkan aktivitas operasinya haruslah dalam keadaan yang menguntungkan/profitable. Tanpa adanya keuntungan akan sulit bagi perusaahaan untuk mencari atau menarik modal dari luar. Perusahaan yang memiliki tingkat profitabilitas yang tinggi sangat diminati oleh investor, sehingga dengan demikian profitabilitas dapat mempengaruhi nilai perusahaan.

Pemilihan rasio profitabilitas didasarkan kepada alasan bahwa rasio profitabilitas menunjukkan efektifitas atau kinerja perusahaan dalam menghasilkan tingkat keuntungan dengan menggunakan asset yang dimiliki. Rasio ini mencerminkan seberapa efektif pengelolaan perusahaan dalam menghasilkan laba bersih dari serangkaian kebijakan pengelolaan asset perusahaan. Profitabilitas merupakan daya tarik utama bagi pemilik perusahaan (pemegang saham) karena hal tersebut adalah hasil yang diperoleh melalui usaha manajemen atas dana yang diinvestasikan oleh para pemegang saham dan juga mencerminkan pembagian laba yang akan menjadi hak para pemegang saham seberapa besar yang diinvestasikan kembali dan seberapa besar yang akan dibayarkan sebagai dividen tunai ataupun dividen saham mereka.

Melalui kebijakan ini perusahaan dapat memberikan sebagian dari keuntungan bersihnya kepada pemegang saham secara tunai (Brigham dan Houston, 2006). Sebagai salah satu cara untuk meningkatkan kemakmuran bagi pemegang saham, khususnya pemegang saham yang berinvestasi dalam jangka panjang dan bukan pemegang saham yang berorientasi capital gain, perusahaan perlu menetapkan kebijakan dividen secara optimal.

Tetapi dalam praktiknya, sering terjadi hambatan untuk merealisasikan tujuan tersebut seperti: terjadinya penurunan profitabilitas, keharusan membayar bunga utang dan atau terbukanya keputusan investasi yang profitable menyebabkan pihak manajemen membatasi pembayaran dividen. Hal ini disebabkan keuntungan yang diperoleh akan dialokasikan menjadi laba ditahan sebagai sumber internal perusahaan. Sehingga mengakibatkan harapan pemegang saham untuk mendapatkan dividen tinggi menjadi pudar. Meskipun demikian, pihak manajemen harus tetap berusaha untuk menghindari terjadinya pemotongan dividen (dividend cut) atau paling tidak membayar dividen secara tetap atau yang dikenal dengan nama Dividend Sticky.

Hal ini disebabkan ada tiga teori yang melatarbelakangi tentang kebijakan dividen. Teori mengenai dividen ini bermula dari bagaimana perlakuan manajer terhadap keuntungan yang diperoleh perusahaan yang pada umumnya sebagian dari 
penghasilan bersih setelah pajak (Earning After Tax / EAT) dibagikan kepada para investor dalam bentuk dividen dan sebagian lagi diinvestasikan kembali ke perusahaan dalam bentuk laba ditahan.

Kebijakan utang atau struktur modal adalah perbandingan pendanaan jangka panjang perusahaan yang ditunjukkan oleh perbandingan utang jangka panjang terhadap modal sendiri. Modal yang digunakan perusahaan selalu melibatkan biaya dalam mendapatkannya. Bagi modal berbentuk utang, biaya dananya relatif mudah untuk diidentifikasikan yaitu, biaya bunga sedangkan bagi modal yang berbentuk modal sendiri, biaya dananya tidak tampak. Meskipun demikian, bukan berarti bahwa biaya dana dari modal sendiri lebih murah daripada biaya dana berbentuk utang.

Penambahan utang akan memperbesar risiko perusahaan, tetapi akan memperbesar tingkat pengembalian yang diharapkan (expected return). Risiko yang semakin tinggi akibat besarnya utang cenderung akan menurunkan harga saham, tetapi meningkatnya expected return yang diharapkan akan meningkatkan harga saham.

Berdasarkan latar belakang penelitian yang telah diuraikan di atas maka rumusan masalah dalam penelitian ini adalah:

1. Apakah Profitabilitas, Pertumbuhan dan Keputusan Investasi berpengaruh secara Simultan dan Parsial Terhadap Kebijakan Dividen?

2. Apakah Kebijakan Utang mampu memperkuat atau memperlemah pengaruh Profitabilitas, Pertumbuhan dan Keputusan Investasi Terhadap Kebijakan Dividen?

Kontribusi penelitian Bagi perusahaan manufaktur yang terdaftar di Bursa Efek Indonesia (BEI) diharapkan dapat dijadikan sebagai bahan informasi dan masukan untuk penilaian mengenai kebijakan dividen. Bagi peneliti dapat menambah wawasan dan pengetahuan peneliti dalam bidang ekonomi khususnya mengenai Kebijakan Dividen pada perusahaan yang terdaftar di Bursa Efek Indonesia. Dan bagi peneliti selanjutnya diharapkan dapat dijadikan sebagai bahan refrensi bagi pihak-pihak yang ingin melakukan penelitian lebih lanjut mengenai Kebijakan Dividen.

\section{B. Landasan Teori}

Dividen merupakan bagian dari keuntungan perusahaan yang didistribusikan kepada para pemegang saham dan pada umumnya dapat dilakukan secara berkala baik dalam bentuk uang (Cash), dividen saham (Stock Dividend), dan dividen ekstra. Dividen ekstra diberikan sebagai tambahan pembayaran dividen pada pemegang saham karena adanya kelebihan harga yang diperoleh perusahaan dari yang diprediksikan. Beberapa penelitian terdahulu yang dapat dijadikan dasar dalam melakukan penelitian ini adalah sebagai berikut:

Penelitian Sunarya (2013) dengan judul penelitian "Pengaruh Kebijakan Utang, Profitabilitas dan Likuiditas terhadap Kebijakan Dividen dengan Size sebagai Variabel Moderasi." Dengan kesimpulan:

a. Kebijakan Utang berpengaruh negatif signifikan terhadap Kebijakan Dividen.

b. Profitabilitas berpengaruh positif signifikan terhadap Kebijakan Dividen.

c. Likuiditas berpengaruh negatif signifikan terhadap kebijakan Dividen.

d. Nilai dari koefisien determinasi $\left(\mathrm{R}^{2}\right)$ menunjukkan bahwa Kebijakan Dividen hanya dapat dijelaskan oleh Variabel Kebijakan Utang, Profitabilitas, Likuiditas, Dummy Size dan interaksi Likuiditas dengan Dummy Size sebesar 8,9\% dan sisanya 91,1\% dijelaskan oleh variabel lainnya. 
Penelitian Sulistiyowati, et. al (2010) dengan judul penelitian "Pengaruh Profitabilitas, Leverage, dan Growth terhadap Kebijakan Dividen dengan Good Corporate Governance sebagai Variabel Intervening " Dengan kesimpulan penelitian:

a. Dalam analisis regresi Profitabilitas, Leverage, dan Growth tidak ada satupun variabel tersebut berpengaruh terhadap Kebijakan Dividen dengan Good Corporate Governance sebagai Variabel Intervening.

b. Dalam path analysys bahwa Profitabilitas, Leverage, dan Growth tidak memiliki pengaruh terhadap Kebijakan Dividen dengan Good Corporate Governance sebagai Variabel Intervening.

Penelitian Sandy dan Asyik (2013) dengan judul penelitian "Pengaruh Profitabilitas dan Leverage terhadap Kebijakan Dividen Kas pada Perusahaan Otomotif". Dengan kesimpulan:

a. Profitabilitas dan Likuiditas secara bersama - sama memiliki pengaruh terhadap Kebijakan dividen Kas.

b. Rasio Profitabilitas tidak memiliki pengaruh signifikan terhadap Kebijakan Deviden Kas.

Penelitian Suharli (2011) dengan judul penelitian "Pengaruh Profitability dan Investment Oppurtunity Set terhadap Kebijakan Dividen dengan Likuiditas sebagai Variabel Penguat" Dengan kesimpulan:

a. Likuiditas dapat digunakan sebagai Variable Penguat dalam mempengaruhi Profitabilitas dan Investment Oppurtunity Set

b. Hanya variabel profitabilitas yang memiliki pengaruh signifikan dalam Kebijakan jumlah pembagian deviden

Penelitian Marpaung dan Hadianto (2009) dengan judul penelitan "Pengaruh Profitabilitas dan Kesempatan Investasi terhadap Kebijakan Dividen; Studi Empirik pada Emiten Pembentuk Indeks LQ45 di Bursa Efek Indonesia.” Dengan kesimpulan penelitian:

a. Profitabilitas memiliki pengaruh Positif signifikan terhadap Kebijakan Dividen

b. Kesempatan investasi diproksikan dengan dua variabel yaitu Pertumbuhan Penjualan dan rasio Harga Pasar terhadap nilai buku dengan hipotesis sebagai berikut:

1. Pertumbuhan Penjualan tidak berpengaruh terhadap Kebijakan Dividen.

2. Rasio Harga Pasar terhadap Nilai Buku (MTBV) memiliki pengaruh positif. Signifikan terhadap Kebijakan Dividen.

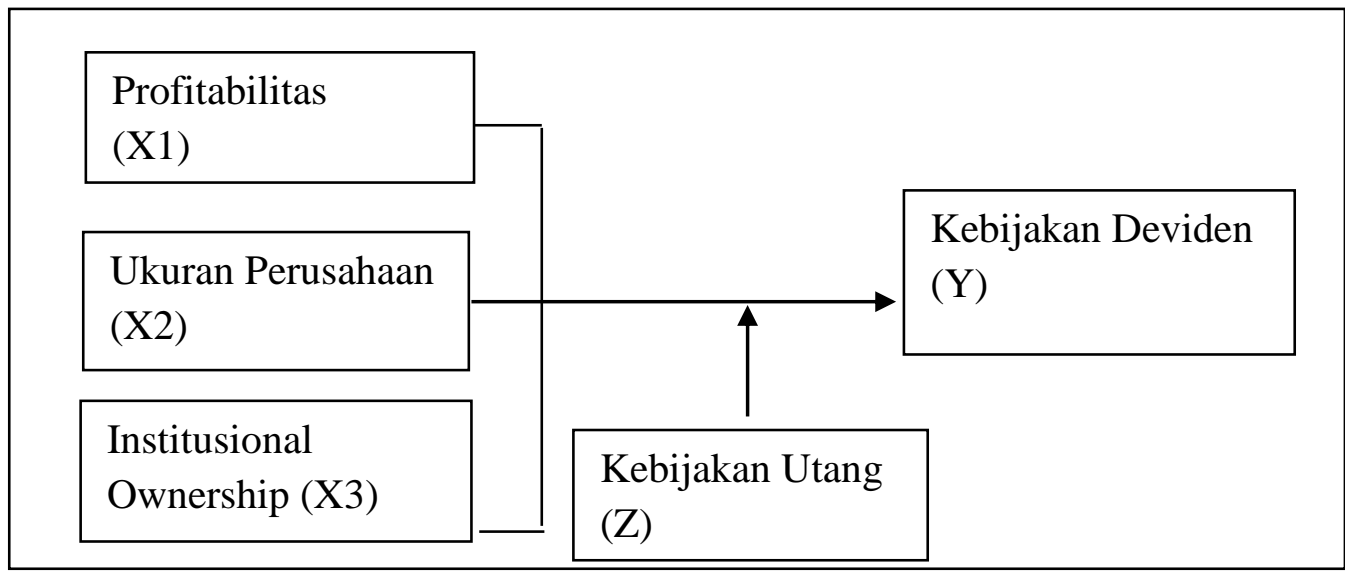

Gambar 1 Kerangka Konseptual 
Kerangka Konseptual menunjukkan pengaruh antar variabel independen terhadap dependen dengan variabel moderating.

\section{a. Pengaruh Profitabilitas terhadap Kebijakan Dividen}

Profitabilitas merupakan keuntungan bersih yang dihasilkan oleh perusahaan dari berbagai aktivitas operasi yang dijalankan oleh pihak manajemen perusahaan. Perusahaan yang memperoleh keuntungan cenderung akan membayar porsi keuntungannya sebagai dividen berdasarkan Rapat Umum Pemegang Saham (RUPS). Semakin besar keuntungan yang diperoleh maka akan semakin besar pula kemampuan perusahaan untuk membayarkan dividen kepada para investor atau pemegang saham. Dengan demikian profitabilitas yang dihasilkan oleh perusahaan digunakan untuk membayarkan dividen. Oleh sebab itu dapat disimpulkan bahwa Profitabilitas berpengaruh positif terhadap Kebijakan Dividen.

\section{b. Pengaruh Pertumbuhan terhadap Kebijakan Dividen}

Pertumbuhan berpengaruh terhadap kebijakan dividen, pertumbuhan yang dimaksud adalah pertumbuhan penjualan. Hal ini disebabkan karena perusahaan mengetahui bahwa terjadi pertumbuhan dalam tingkat penjualan, sehingga tidak menjadi permasalahan apabila perusahaan meningkatkan jumlah dividen yang akan dibagikan atau perusahaan ingin menarik perhatian para investor sehingga memberikan dividen guna memberikan kepercayaan terhadap hasil investasi kepada para investor.

\section{c. Pengaruh Keputusan Investasi terhadap Kebijakan Deviden}

Keputusan investasi di suatu perusahaan menyangkut pemilihan terhadap investasi yang diinginkan untuk memperoleh keuntungan dari berbagai kesempatan investasi yang ada, yaitu dengan memilih salah satu atau lebih alternatif investasi yang dinilai paling menguntungkan investor.

Pihak Manajemen memiliki kepentingan yang berbeda dengan para investor yaitu keuntungan perusahaan tidak dibagi dalam bentuk dividen kepada para investor dengan tujuan untuk dipergunakan dalam kegiatan pengembangan investasi lainnya, sedangkan para investor disamping keuntungan dapat dibagi dalam bentuk dividen keuntungan tersebut dapat dipergunakan untuk kegiatan investasi lainnya. Sehingga Keputusan Investasi dapat mempengaruhi secara positif terhadap kebijakan dividen yang akan dijalankan oleh manajemen perusahaan.

\section{d. Pengaruh Profitabilitas, Keputusan Investasi terhadap Kebijakan Dividen dengan Kebijakan Utang sebagai variabel Moderating.}

Suatu Perusahaan jika dikelola dengan baik akan berjalan sesuai dengan harapan yang diinginkan baik pemilik saham, manajemen perusahaan maupun pekerja, dengan pengelolaan yang baik maka tujuan utama profitabilitas akan semakin baik dan meningkat. Tingkat laba yang tinggi akan memberikan manfaat yang besar bagi perusahaan sehingga perusahaan cenderung menggunakan sumber dana dari internal dari pada external, sehingga pengaruh Profitabilitas terhadap Kebijakan Dividen melalui Kebijakan Utang.

Pada Umumnya Perusahaan yang memiliki tingkat profitabilitas yang baik tentunyua akan memikirkan kegiatan investasi apa yang harus ditingkatkan untuk menambah keuntungan Perusahaan dimasa yang akan datang. Dalam menjalankan investasi, dana yang dipergunakan berasal dari keuntungan perusahaan dan dapat juga 
diperoleh dari Lembaga Pendanaan/Pembiayaan jika kegiatan investasi membutuhkan dana yang cukup besar. Sehingga menunjukkan hubungan yang positif Keputusan Investasi dengan Kebijakan Utang.

Berdasarkan perumusan masalah dan kerangka konseptual sebagaimana yang telah diuraikan di muka, maka hipotesis dalam penelitian ini adalah:

1. Profitabilitas, Pertumbuhan, dan Keputusan Investasi berpengaruh positif terhadap Kebijakan Deviden

2. Kebijakan Utang mampu memoderasi pengaruh Profitabilitas, Pertumbuhan, Keputusan Investasi terhadap Kebijakan Dividen

\section{Metode Penelitian}

Populasi dalam penelitian ini adalah seluruh perusahaan manufaktur yang terdaftar di Bursa Efek Indonesia (BEI) yang mempublikasikan laporan keuangan tahunan yang telah di audit periode 2012 - 2016 yang berjumlah 138 perusahaan. Sampel yang diambil dengan menggunakan metode Purposive Samling dengan kriteria: (1) Perusahaan manufaktur yang terdaftar di Bursa Efek Indonesia (BEI) secara berturut - turut dari tahun 2012 - 2016. (2) Perusahaan yang mempublikasikan laporan keuangan yang di audit secara berturut - turut selama 5 tahun. (3). Perusahaan yang mempunyai laba selama 5 tahun berturut - turut yang dimulai dari tahun 2012 - 2016 . Berdasarkan kriteria tersebut diperoleh sampel akhir berjumlah 85 perusahaan. Penelitian ini menggunakan pooling data yakni dengan menggunakan data time series 5 tahun pengamatan dimulai tahun 2012 - 2016. Dan cross section yaitu sebanyak 85 perusahaan. Jumlah observasi yaitu sebanyak 425 data analisis yaitu dengan cara 5 tahun pengamatan X 85 perusahaan. Data yang digunakan dalam penelitian ini adalah berupa data sekunder, yaitu data kuantitatif yang di unduh dari situs resmi Bursa Efek Indonesia www.idx.co.id.

Definisi operasional variabel dan pengukuran variabel yang akan digunakan pada penelitian ini adalah sebagai berikut:

\section{Variabel Dependen}

\section{Kebijakan Dividen (Y)}

Kebijakan Dividen merupakan bagian yang tidak dapat dipisahkan dengan keputusan pendanaan perusahaan, karena kebijakan dividen adalah kebijakan untuk menentukan berapa laba yang harus dibayarkan dalam bentuk dividen kepada para pemegang saham dan berapa banyak yang harus ditanam kembali (laba ditahan). Kebijakan dividen dalam penelitian ini diproksikan dengan Dividen Payout Ratio (DPR).

\section{Variabel Independen}

\section{Profitabilitas}

Profitabilitas merupakan kemampuan perusahaan untuk mendapatkan keuntungan dari setiap berbagai aktivitas produksi perusahaan. Dalam penelitian ini digunakan proksi Return On Asset (ROA) yaitu dengan pembagian Net Income dibagi dengan Total Asset. 


\section{Pertumbuhan}

Pertumbuhan merupakan kenaikan pendapatan (revenues) yang merupakan arus kas masuk yang diperoleh dan yang akan diperoleh yang berasal dari aktivitas usaha perusahaan yang masih berlangsung. Pendapatan meliputi arus kas masuk seperti penjualan tunai, dan arus kas masuk prospektif seperti penjualan kredit.

\section{Keputusan Investasi}

Keputusan investasi adalah keputusan bisnis di luar keputusan keuangan. Keputusan ini tercermin pada sisi kiri neraca yang mengungkapkan berapa besar aktiva lancar, aktiva tetap dan aktiva lainnya yang dimiliki. Keputusan investasi dalam penelitian ini diproksikan dengan Price Earning Ratio (PER).

\section{Variabel Moderating}

\section{Kebijakan Utang}

Kebijakan utang adalah kebijakan perusahaan untuk mendanai aktivitas operasi perusahaan dan dapat juga digunakan untuk ekspansi yang diperoleh dari pihak ketiga yang dapat diproksikan dengan Debt to Equity Ratio (DER).

Model analisis data yang digunakan adalah analisis regresi linier berganda yang bertujuan untuk menguji dan menganalisis pengaruh Profitabilitas, Cash Position dan Keputusan Investasi terhadap Kebijakan Dividen dengan Kebijakan Utang sebagai Variabel Moderating. Model analisis data yang dipergunakan untuk menjawab hipotesis penelitian di atas adalah sebagai berikut:

$$
\begin{aligned}
& Y=b_{1} X_{1}+b_{2} X_{2}+b_{3} X_{3}+c \\
& Z=c_{1} X_{1}+c_{2} X_{2}+c_{3} X_{3}+c \\
& I c I=d_{0}+d_{1} Y
\end{aligned}
$$

Variabel - variabel penelitian yang disajikan dalam tabel descriptive statistics, variabel penelitian menunjukkan nilai minimum, nilai maksimum, nilai rata - rata dan standar deviasi. Apabila nilai standar deviasi lebih kecil dari nilai rata - rata maka data tersebut berdistribusi normal.

\section{Hasil}

Pada tabel Descriptive Statistics menunjukkan gambaran mengenai variabel variabel penelitian disajikan bahwa variabel penelitian menunjukkan nilai minimum, nilai maksimum, nilai rata - rata dan standar deviasi. Apabila nilai Standar Deviasi lebih kecil daripada nilai rata - rata maka data berdistribusi normal. Pada penelitian ini nilai standar deviasi lebih kecil daripada nilai rata - rata, dapat dikatakan bahwa data penelitian berdistribusi normal.

\section{Uji Normalitas Data}

Uji normalitas data akan dideteksi melalui analisa grafik yang dihasilkan melalui perhitungan regresi dengan menggunakan software SPSS. Hasil uji normalitas data dapat dilihat dari grafik dan One Sample Kolmogorov Smirnov Test. Berdasarkan hasil Kolmogorov Smirnov Test dengan nilai Asymp. Sig. (2-tailed) sebesar 0,636 $>\alpha=5 \%$ $(0,05)$ ini berarti bahwa data berdistribusi normal. Penelitian ini sudah bebas dari uji normalitas data, maka data sudah berdistribusi dengan normal. 


\section{Uji Multikolinieritas}

Pada penelitian ini dapat dilihat bahwa hasil olah data tidak menunjukkan ada terjadinya multikolinieritas. Dalam hal ini nilai daripada masing - masing variabel memenuhi kriteria yaitu nilai Tolerance $>0,1$ dan nilai VIF $<5$. Profitabilitas mempunyai nilai tolerannce sebesar $0,822>0,1$ dan VIF sebesar 1,216 < Pertumbuhan nilai tolerance sebesar $0,998>0,1$ dan VIF sebesar 1,002 < 5, dan Keputusan Investasi nilai tolerance sebesar 0,8222 > 0,1 dan VIF sebesar 1,217< 5 . Dari penjelasan di atas maka dapat disimpulkan bahwa data tersebut tidak terjadi multikolinieritas.

\section{Uji Autokorelasi.}

Peneliti menggunakan uji autokorelasi dengan menggunakan uji Runs test yaitu dengan melihat nilai Asymp. Sig. (2-tailed). Apabila nilai Asymp. Sig (2-tailed) $>\alpha=$ $5 \%(0,05)$ maka dapat dikatakan bahwa data tidak terjadi autokorelasi. Berdasarkan hasil runs test dengan nilai Asymp. Sig. (2-tailed) sebesar 0,808 $>\alpha=5 \%(0,05)$ ini berarti bahwa data tidak terjadi autokorelasi.

\section{Uji Heteroskedastisitas.}

Dari hasil di atas memperlihatkan bahwa titik - titik menyebar di sekitar titik nol, serta tidak tampak adanya suatu pola tertentu pada sebaran tersebut. Maka dapat disimpulkan bahwa model regresi tersebut memenuhi uji heterokedastisitas atau dengan kata lain tidak terjadi heterokedastisitas.

Tabel 1 Persamaan Regresi 1 (Pertama)

\begin{tabular}{|c|c|c|c|c|c|c|}
\hline \multicolumn{7}{|c|}{ Coefficient $^{\mathrm{a}}$} \\
\hline \multirow{2}{*}{\multicolumn{2}{|c|}{ Model }} & \multicolumn{2}{|c|}{$\begin{array}{l}\text { Unstandardized } \\
\text { Coefficients }\end{array}$} & \multirow{2}{*}{$\begin{array}{c}\begin{array}{c}\text { Standardized } \\
\text { Coefficients }\end{array} \\
\text { Beta }\end{array}$} & \multirow[b]{2}{*}{$\mathrm{t}$} & \multirow[b]{2}{*}{ Sig. } \\
\hline & & $\mathrm{B}$ & Std. Error & & & \\
\hline 1 & (Constant) &, 032 &, 043 & &, 742 &, 458 \\
\hline & Profitabilitas & 1,474 &, 100 & 643 & 14,800 & ,000 \\
\hline & Pertumbuhan &, 052 & 057 & 036 & ,921 & ,357 \\
\hline & Keputusan Investasi & ,891 &, 178 & ,217 & 5,001 & ,000 \\
\hline
\end{tabular}

a. Dependent Variable: Kebijakan Dividen

b.

Tabel 2 Persamaan Regresi 2 (Kedua)

Coefficient $^{\mathrm{a}}$

\begin{tabular}{|c|c|c|c|c|c|c|}
\hline \multirow{2}{*}{\multicolumn{2}{|c|}{ Model }} & \multicolumn{2}{|c|}{$\begin{array}{c}\text { Unstandardized } \\
\text { Coefficients }\end{array}$} & \multirow{2}{*}{$\begin{array}{c}\text { Standardized } \\
\text { Coefficients } \\
\text { Beta } \\
\end{array}$} & \multirow[b]{2}{*}{$\mathrm{t}$} & \multirow[b]{2}{*}{ Sig. } \\
\hline & & $\mathrm{B}$ & Std. Error & & & \\
\hline \multirow[t]{4}{*}{1} & (Constant) & 1,011 &, 150 & & 6,756 &, 000 \\
\hline & Profitabilitas &,- 361 & ,349 &,- 050 & $-1,033$ & ,302 \\
\hline & Pertumbuhan &,- 050 & , 199 &,- 012 &,- 254 & ,800 \\
\hline & Keputusan Investasi &,- 539 & ,625 &,- 046 &,- 864 & ,388 \\
\hline
\end{tabular}

a. Dependent Variable: Kebijakan Utang 
Tabel 3 Persamaan Regresi 3 (Ketiga)

Coefficient $^{\mathrm{a}}$

\begin{tabular}{|c|c|c|c|c|c|c|}
\hline \multirow{2}{*}{\multicolumn{2}{|c|}{ Model }} & \multicolumn{2}{|c|}{$\begin{array}{c}\text { Unstandardized } \\
\text { Coefficients }\end{array}$} & \multirow{2}{*}{$\begin{array}{l}\text { Standardized } \\
\text { Coefficients } \\
\text { Beta }\end{array}$} & \multirow[b]{2}{*}{$\mathrm{t}$} & \multirow[b]{2}{*}{ Sig. } \\
\hline & & B & Std. Error & & & \\
\hline 1 & (Constant) & ,534 & ,041 & & 13,005 &, 000 \\
\hline & $\begin{array}{l}\text { Kebijakan } \\
\text { Dividen }\end{array}$ &,- 037 & ,084 &,- 021 &,- 440 & 660 \\
\hline
\end{tabular}

a. Dependent Variable: Moderating

Berdasarkan tabel 1, tabel 2, dan tabel 3, dari persamaan regresi diatas maka model regresi antara variabel independen [Profitabilitas, Pertumbuhan, Keputusan Investasi] dan variabel moderating Kebijakan Utang dengan variabel dependen Kebijakan Dividen adalah sebagai berikut:

\section{a. Pengaruh Profitabilitas terhadap Kebijakan Dividen}

Berdasarkan tabel 1 persamaan regresi pertama terlihat bahwa Profitabilitas berpengaruh positif dan signifikan terhadap Kebijakan Dividen. Dimana nilai Unstandardized Coefficient Beta (B) bernilai positif $(1,474)$ dan nilai signifikansinya (Sig.) sebesar $(0,000)<$ Sig. 0,05 (5\%).

\section{b. Pengaruh Pertumbuhan terhadap Kebijakan Dividen}

Berdasarkan tabel 1 persamaan regresi pertama terlihat bahwa Pertumbuhan berpengaruh positif tidak signifikan terhadap Kebijakan. Dimana nilai Unstandardized Coefficient Beta (B) bernilai positif $(0,052)$ dan nilai signifikansinya (Sig.) sebesar $(0,357)>$ Sig. 0,05 (5\%).

\section{c. Pengaruh Keputusan Investasi (PER) terhadap Kebijakan Dividen (DPR)}

Berdasarkan tabel 1 persamaan regresi pertama terlihat bahwa Keputusan Investasi berpengaruh positif signifikan terhadap Kebijakan Dividen. Dimana nilai Unstandardized Coefficient Beta (B) bernilai Positif $(0,891)$ dan nilai signifikansinya (Sig) sebesar $(0,000)<$ Sig. 0,05 (5\%).

d. Pengaruh Profitabilitas, Keputusan Investasi Terhadap Kebijakan Dividen dengan Kebijakan Utang sebagai variabel moderating.

Berdasarkan tabel 3 persamaan regresi ketiga menunjukkan bahwa nilai Unstandardized Coefficients/ koefisien parameternya bernilai negatif $(-0,440)$ dan nilai signifikansinya (Sig.) sebesar 0,660 > Sig. 0,05 (5\%). Dapat disimpulkan bahwa Kebijakan Utang (DER) mampu memperlemah pengaruh Profitabilitas (ROA), Pertumbuhan dan Keputusan Investasi (PER) terhadap Kebijakan Dividen (DPR).

\section{Pengujian Hipotesis}

Analisis data dilakukan dengan menggunakan regresi linier berganda yang bertujuan untuk mengetahui dan menganaisis pengaruh Profitabilitas, Cash Position, dan Keputusan Investasi terhadap Kebijakan Dividen dengan Kebijakan Utang sebagai variabel moderating pada perusahaan manufaktur yang terdaftar di Bursa Efek Indonesia (BEI). Data diolah dengan menggunakan program komputer Statistical 
Package For Social Science (SPSS). Pengujian hipotesis ini di uji dengan menggunakan uji statistik - F, uji statistik - $\mathrm{t}$, dan uji koefisien determinasi $\left(\mathrm{R}^{2}\right)$.

Dependent Variable: Kebijakan Dividen

\begin{tabular}{|c|c|c|c|c|c|c|}
\hline \multicolumn{7}{|c|}{$\begin{array}{l}\text { Uji Statistik - F } \\
\left.\text { Tabel 4.4 Uji Statistik F (ANOVA }{ }^{\text {b }}\right)\end{array}$} \\
\hline \multicolumn{2}{|c|}{ Model } & $\begin{array}{l}\text { Sum of } \\
\text { Squares }\end{array}$ & df & $\begin{array}{l}\text { Mean } \\
\text { Square }\end{array}$ & $\mathrm{F}$ & Sig. \\
\hline \multirow[t]{3}{*}{1} & Regression & 7,847 & 3 & 2,616 & 74,216 &, $000^{\mathrm{a}}$ \\
\hline & Residual & 14,837 & 421 & ,035 & & \\
\hline & Total & 22,683 & 424 & & & \\
\hline
\end{tabular}

Dari uji hipotesis yaitu uji simultan (Uji statistik F) yaitu nilai sig. sebesar 0,000 $<\alpha=5 \%(0,05)$ yang dilakukan maka diperoleh hipotesis yaitu profitabilitas, kebijakan hutang, kebijakan dividen, keputusan investasi dan insider ownership memiliki pengaruh secara simultan terhadap nilai perusahaan.

\section{E. Kesimpulan dan Keterbatasan penelitian}

\section{Kesimpulan}

1. Profitabilitas, Pertumbuhan, dan Keputusan Investasi secara simultan atau serempak berpengaruh terhadap Kebijakan Dividen.

2. Secara Parsial Profitabilitas, dan Keputusan Investasi berpengaruh positif dan signifikan terhadap Kebijakan Dividen, sedangkan Pertumbuhan berpengaruh positif dan tidak signifikan terhadap Kebijakn Dividen.

3. Variabel Kebijakan Utang mampu memperlemah pengaruh Profitabilitas, Pertumbuhan dan Keputusan Investasi terhadap Kebijakan Dividen.

\section{Keterbatasan Penelitian}

Keterbatasan variabel independen yang digunakan dalam memprediksi variabel dependen dan keterbatasan jumlah data penelitian terkait dengan banyaknya data yang yang dikeluarkan setelah dilakukan kriteria pengambilan sampel sehingga mengakibatkan pengolahan data tidak dapat dilakukan pada tingkat jumlah sampel yang maksimal.

Sebagai saran, dapat melakukan penambahan variabel independen seperti: ukuran perusahaan (SIZE), Institutional Ownership (IO), tingkat suku bunga (SBBI) dan lain - lain. Dan dapat menambah tahun pengamatan mulai tahun 2010 - 2016 agar jumlah sampel dan jumlah data observasi lebih banyak. 


\section{F. Daftar Pustaka}

Ayuningtias, Dwi dan Kurnia. 2013. Pengaruh Profitabilitas Terhadap Nilai Perusahaan ; Kebijakan Dividen dan Kesempatan Investasi Sebagai Variabel Antara.

Brigham, Eugene F. dan Joel F. Houston. 2006 Dasar-Dasar Manajemen Keuangan, Buku 1, penerbit Salemba Empat, Jakarta.

Dewi, S.C., 2008. Pengaruh Kepemilikan Managerial, Kepemilikan Institusional, Kebijakan Hutang, Profitabilitas dan Ukuran Perusahaan terhadap Kebijakan Dividen, Jurnal Bisnis dan Akuntansi, Vol.10. NO.1:48-57.

Erlina. 2011. Metodologi Penelitian. Cetakan Pertama: ISBN: 979 458. Art Design, Publishing \& Printing. Medan.

Ghozali, Imam. 2013. Aplikasi Analisis Multivariate dengan Program IBM SPSS 21 Up Date PLS Regresi, Cetakan Ketujuh: ISBN: 979.704.015.1. Penerbit: Badan Penerbit Universitas Diponegoro, Semarang.

Hermuningsih, Sri. dan Dewi Kusuma Wardani. 2009. Faktor - Faktor yang mempengaruhi Nilai Perusahaan Pada Perusahaan yang Terdaftar di Bursa Efek Malaysia dan Bursa Efek Indonesia. Jurnal Siasat Bisnis Vol. 13 No. 2. Hal: 173-183.

Marpaung, Elyzabet Indrawati dan Bram Hadianto. 2009. Pengaruh Profitabilitas dan Kesempatan Investasi Terhadap Kebijakan Deviden; Studi Empirik pada Emiten Pembentuk Indeks LQ45 di Bursa Efek Indonesia. Jurnal Akuntansi Vol. 1 No. 1. Hal: 70-78.

Sandy, Ahmad, dan Nur Fadjrih Asyik. 2013. Pengaruh Profitabilitas dan Likuiditas Terhadap Kebijakan Deviden Kas Pada Perusahaan Otomotif, Jurnal Ilmu dan Riest Akuntansi Vol 1 No. 1. 58:76.

Suhardi, Michell. 2007. Pengaruh Profitabilitas dan Investmen Oppurtun.9-17ity Set Terhadap Kebijakan Deviden dengan Likuidits sebagai Variable Penguat. Jurnal Akuntansi dan Keuangan Vol.9 No.1

Sulistiyowati, Indah, Ratna Anggraini dan Tri Hesti Utaminingtyas. 2010. Pengaruh Profitabilitas, Leverage dan Gorwth Terhadap Kebijakan Deviden dengan Corporate Social Responsibility sebagai Variable Intervening. Simposium Nasional Akuntansi XIII Perwokerto 2013..

Sunarya, Devi, Hoe. 2013. Pengaruh Kebijakan Utang, Profitabilias dan Likuiditas Terhadap Kebijakan Deviden dengan Size Sebagai Variable Moderasi Pada Sektor Manufaktur Periode 2008-2011. Jurnal Ilmiah Mahasiswa Universitas Surabaya Vol. 2 No. 1. Hal: 3-19.

Wahyudi, U., dan H. P. Pawestri, 2006, "Implikasi Struktur Kepemilikan Terhadap Nilai Perusahaan: dengan Keputusan Keuangan sebagai Variabel Intervening”, Makalah Simposium Nasional Akuntansi,9, Padang. 